\title{
Corporate Entrepreneurship and Manufacturing Firms' Performance
}

\section{Benneth Uchenna Eze}

Hallmark University, Nigeria | beneze7@gmail.com

Volume 8 No 1 (2018) ｜ ISSN 2158-8708 (online) ｜ DOI 10.5195/emaj.2018.146 | http://emaj.pitt.edu |

\begin{abstract}
The study evaluates the effect of corporate entrepreneurship (measured by innovation, proactiveness, risk-taking, strategic renewal and corporate venturing) on the non-financial performance of manufacturing firms in Nigeria (measured by market share and employees satisfaction). The study employed survey research design, through the administration of structured questionnaire to management staff of eight manufacturing firms in Nigeria. The findings revealed that innovation, risk taking, proactiveness, strategic renewal and corporate venturing are all significantly related with manufacturing firms' nonfinancial performance. It can therefore be concluded that corporate entrepreneurship (CE) elements (risk-taking, innovation, corporate venturing, proactiveness and strategic renewal) enhance manufacturing firms' non-financial performance (market share and employees' satisfaction). It is recommended that manufacturing firms should employ CE elements towards the enhancement of their non-financial performance.
\end{abstract}

Keywords: Corporate Entrepreneurship, Manufacturing Firms, Non-Financial Performance, Innovation, Proactiveness, Risk-Taking, Strategic Renewal, Corporate Venturing

\section{$(\mathrm{cc}) \mathrm{EY}$}

New articles in this journal are licensed under a Creative Commons Attribution 3.0 United States License.

\section{UILIS D-Sonk}

This journal is published by the University Library System of the University of Pittsburgh as part of its $\underline{\mathrm{D} \text {-Scribe Digital Publishing Program, and is cosponsored by the University of Pittsburgh Press. }}$ 


\section{Corporate Entrepreneurship and Manufacturing Firms' Performance}

\section{Benneth Uchenna Eze}

\section{Introduction}

The importance of the manufacturing sector of Nigeria economy cannot be overemphasized. The manufacturing sector adds value to the overall economic growth, creates more jobs than any other sector (World Economic Forum, 2013). However, the manufacturing sector in Nigeria is plagued by some challenges, among which are: increasing cost of production, emanating from increased cost of energy and increasing cost of imported raw material, reliance on inadequate and poor public infrastructure, as well as the depreciation of the local currency (Naira) (Akinmulegun \& Oluwole, 2014).

Firms have employed various conceptual elements to enhance their performance. One of such conceptual elements is corporate entrepreneurship (CE), which refers to the entrepreneurial activities of corporate organizations and its components. These include: Risktaking, innovation, proactiveness, corporate venturing and strategic renewal. Studies have shown that CE positively and significantly affects firm's performance (Daryani and Karimi, 2017; Jancenelle et al., 2017; Prange and Pinho, 2017; Abosede, Fayose and Eze, 2018).

Although, most of the studies employed financial performance measures; the effect of $\mathrm{CE}$ on the nonfinancial performance of the manufacturing firms in Nigeria appears not to have been fully explored. The few studies on the subject matter in Nigeria focused on how $\mathrm{CE}$ has impacted manufacturing firms' financial performance. Ibrahim and Lloyd (2011) opine that high performance on non-financial performance measures tend to enhance the future financial performance of firms. In this way, non-financial performance measures can lead to an enhancement in financial performance measures. For instance, an increase in market share (which is a non-financial measure of performance) tends to increase revenue and profitability (which is a financial performance indicator). Similarly, an increase in employees' satisfaction level (which is a non-financial performance measure) tends to prompt employees to put in more effort, which can lead to more sales revenue for such firms.

In addressing this research gap, this study examines the effect of CE (measured by risk-taking, proactiveness, innovation, strategic renewal and corporate venturing) on the non-financial performance (measured employee's satisfaction and market share) of manufacturing firms in Nigeria. The objective of the study is to examine the effects of innovation, risk-taking, proactiveness, strategic renewal and corporate venturing on the market share and employee's satisfaction level of manufacturing firms in Nigeria.

The study was divided into five sections: Section one introduces the subject matter. It presents the problem statement (based on the relevant literature and with references to the literature), the research gap and the objectives of the study. Section two presents a review of literature. Section three presents the research methodology employed for this study. Section four presents the research findings and discussion of the findings. Section five provides the conclusion and recommendations of the study. Finally, section six presents suggestions for future studies.

\section{Literature Review}

The manufacturing sector has become increasingly important as the driver of economic growth in developed, emerging and developing economies (Oburota and Ifere, 2017). Considering the enormous role that the manufacturing sector is expected to play in the industrialization of the Nigerian economy, the sector seems not to be contributing much to the economic growth of Nigeria. According to Central Bank of Nigeria (CBN) (2012), the contribution of the manufacturing sector in Nigeria to the nations' GDP is relatively low. The low contribution of the manufacturing sector to the nation's GDP is as a result of numerous challenges confronting the sector. These challenges include: Lack of infrastructural facilities like good road network, functional transportation system (especially rail transportation), high cost of imported raw materials (due to the devaluation of Naira and high import duties), high cost of power (due to the nation's epileptic power supply that has led manufacturers to seek alternative source of power at high cost).

The concept of CE has evolved over time. Early research on CE focused on the development of entrepreneurship within existing firms and venture teams (Hill and Hlavacek, 1972; Peterson and Berger, 1972; Hanan, 1976). In the 1980 's, researchers conceptualized $\mathrm{CE}$ as relating to entrepreneurial activities, aimed at developing value creating innovative actions, which entail the commitment of resources and approval of an organization (Schollhammer, 1982; Burgelman, 1984; Pinchott, 1985; Kuratko and Montagno,1989). Contemporary studies have seen the linkage of CE to firms' international performance (Abosede, Fayose and Eze, 2018), as well as firms financial performance (Daryani and Karimi, 2017; Jancenelle et al., 2017). Wolcot and Lippitz (2007) posit that CE refers to a process, through which teams within existing business entity develop and manage a new business that is separate from the parent firm, but leverages the parent's assets, market position, capabilities or other resources. Thornberry (2003) opines that CE is also responsible for stimulating innovation within the firm through the evaluation of potentially new opportunities, resource acquisition, execution, exploitation and commercialization of the new products or services. For this study, CE is viewed as the entrepreneurial activities of business entities, which involve the innovative, proactive, risk-taking, strategic renewal and corporate venturing activities of business entities. 
Miller and Friesen (1982) measured CE by employing the following constructs: Proactiveness, innovation and risk taking. Zahra (1995) highlights three components of $\mathrm{CE}$, innovation, strategic renewal, and corporate venturing. In this case, innovation entails firms' commitment to the introduction of new products, process and market. Venturing implies the creation of new business and strategic renewal refers to the combinations of resources towards wealth creation (Zahra, 1995).

Risk taking involves taking bold steps, by entering into the uncertain business environment and borrowing heavily. Zahra and Garvis (2000) opine that risk taking is a firm's disposition to embark on innovative projects irrespective of how uncertain such business activities are. Proactiveness reveals a firm's quest for business opportunities and an emphasis on being among the early movers to employ innovativeness in its industry (Rauch et al., 2009). Proactiveness is a futuristic and opportunity-seeking perspective typified by product introduction ahead of the competitors and acting in expectation of future demand. Wiklund (1999) posits that proactiveness gives firms the ability to introduce new products or services to the market ahead of its competitors, which is also a source of competitive advantage.

Some scholars have examined how firms can enhance their performance by employing corporate entrepreneurship elements. Adele (2015) posits that CE tends to enhance manufacturing firms' financial performance in Nigeria. Oyedokun (2015) posits that CE enhances the dynamic capabilities of pharmaceutical firms in Nigeria.

Prange and Pinho (2017) found that innovation enhances the performance of small and medium sized enterprises (SMEs). In a similar study, Daryani and Karimi (2017) equally found that CE significantly influences the performance of SMEs in Iran. Jancelle et al. (2017) found that CE elements, risk-taking and innovativeness positively and significantly affect firms' performance. Abosede, Fayose and Eze (2018) found that $\mathrm{CE}$ enhances the international performance of banks in Nigeria.

The theory underpinning this study is the Benneth theory of corporate entrepreneurship. The theory assumes that there are only five elements of corporate entrepreneurship, which are risk taking, innovation, proactiveness, corporate venturing and strategic renewal. The theory postulates that corporate entrepreneurial activities of firms tend to enhance their performance as well as their international expansion. This theory emerges from models specified by Abosede, Oladimeji and Eze (2017); Oladimeji, Abosede and Eze (2017); Abosede, Fayose and Eze (2018). The models were used to test the effects of innovation on the internationalization of banks; corporate entrepreneurship on the performance of service firms; corporate entrepreneurship on the international performance of banks. These studies found that corporate entrepreneurship elements have a combined effect on firms' performance, internationalization and international performance. The theory was employed by Oladimeji, Eze and Adebayo (in press); Eze (in press) to examine the effects of strategic renewal and corporate venturing on the internationalization of Nigerian banks as well as risk taking and proactiveness on the internationalization of Nigerian banks.

\section{Data and Methodology}

Survey research design was employed for the study, through the administration of structured questionnaire to management staff of eight manufacturing firms in Nigeria. These firms cut across the following sub-sectors of the manufacturing sector: Fast moving consumers goods sub-sector, beverages sub-sector, chemical and allied products sub-sector and pharmaceutical manufacturers. Two manufacturing firms were purposively selected from each of the four sub-sectors. The eight manufacturing firms used for this study are: Dangote Sugar PLC, Honeywell Flour Mills PLC, Berger Paint PLC, President Paint PLC, Emzor Pharmaceutical, May \& Baker PLC, 7 Up Bottling Company PLC and Nigeria Bottling Company PLC.

According to National Bureau of statistics (2014), the manufacturing sectors employs 2, 368, 514 people, which constitute the population for this study. Considering Yamane (1968), based on sample size determination formula at $95 \%$ confidence interval and 5 degree of error, a sample size of 400 was derived. Wellstructured questionnaire on a nine-point Likert scale ranging from 1 (minimum) to 9 (Maximum) was administered to the targeted respondents. 400 copies of questionnaire were administered. However, 298 copies of the questionnaire were returned and found useable, which represents $74.5 \%$ return rate.

The instrument (questionnaire) was validated, using content validity. The validity of the instrument was tested using content validity index (CVI) by making use of four independent evaluators (four academics). Each of the independent evaluators rated the questions on a two point rating scale of 'relevant' (R) and 'not relevant' (NR). The content validity index was obtained by employing the CVI formula:

$\mathrm{CVI}=\mathrm{n} / \mathrm{N}$

Where;

$\mathrm{N}=$ Total number of items in the instrument $\mathrm{n}=$ numbers of items rated as relevant.

The CVI gave a value of 0.7890 , which indicated that the instrument is valid.

The Cronbach Alpha was employed to test the reliability of the instrument through a pilot study. The instruments were administered twice within an interval of two weeks and the results of the first and second pilot studies were correlated and a Cronbach Alpha of 0.7703 , $0.8911,0.9021,0.8934,0.8822,0.7912$ and 0.8524 were obtained for innovation, risk taking, proactiveness, strategic renewal, corporate venturing, employee's satisfaction and market share respectively. Nunnally (1978) posits that the acceptable reliability level is an alpha coefficient greater than 0.7. Therefore, the instrument is reliable. 
Statement of Hypothesis:

$\mathrm{Ho}_{1}$ : Innovation has no significant effect on the nonfinancial performance of manufacturing firms in Nigeria.

$\mathrm{Ho}_{2}$ : Proactiveness does not have a significant effect on the non-financial performance of manufacturing firms in Nigeria.

$\mathrm{Ho}_{3}$ : Risk taking has no significant effect on the non-financial performance of manufacturing firms in Nigeria.

$\mathrm{Ho}_{4}$ : Strategic renewal does not significantly affect the non-financial performance of manufacturing firms in Nigeria.

$\mathrm{Ho}_{5}$ : Corporate venturing does not have a significant effect on the non-financial performance of manufacturing firms in Nigeria.

$\mathrm{Ho}_{6}$ : Combined corporate entrepreneurship elements do not have significant effect on the non-financial performance of manufacturing firms in Nigeria.

Model Specification:

The theory underpinning the model specification for this study is Benneth theory of corporate entrepreneurship. The theory is relevant to this study, because it captures all the variables employed for this study (proactiveness, strategic renewal, innovation, risk taking, corporate venturing and firm's performance).

The model specification is stated below:

NONFIN $=$

$f(I N V, P R, R T, S R, C V)$

NONFIN $=$

$\beta_{0}+\beta_{1} I N V_{i}+\beta_{2} P R_{i} \beta_{3} R T i+\beta_{4} S R i+\beta_{5} C V i+\mu_{i}-$ $-----(i i)$

Where;

NONFIN represents non-financial performance

$\beta_{0}$ is the constant term

$\beta_{1}, \beta_{2}, \beta_{3}, \beta_{4}, \beta_{5}$ are the coefficients of the estimator.

$\beta_{1}, \beta_{2}, \beta_{3}, \beta_{4}, \beta_{5}>0$

INV= Innovation

$\mathrm{PR}=$ Proactiveness

RT $=$ Risk Taking

$\mathrm{SR}=$ Strategic Renewal

$\mathrm{CV}=$ Corporate Venturing

$\mu$ is the error term

The apriori expectation: It is expected that innovation, proactiveness, risk taking, strategic renewal and corporate venturing will all have a positive effect on the non-financial performance of manufacturing firms; hence the parameters of innovation, proactiveness, risk taking, strategic renewal and corporate venturing should all have a positive sign. Structural equation models (SEM) was used to test whether there is a measurable relationship between corporate entrepreneurship and manufacturing firms' performance, with the aid of Linear Structural Equations (LISREL) Software.

\section{Empirical Findings and Discussion}

Table 1: Independent and Dependent Variables

\begin{tabular}{|c|c|c|c|c|}
\hline \multirow[t]{2}{*}{$\begin{array}{l}\text { Independent } \\
\text { variables }\end{array}$} & \multicolumn{4}{|c|}{$\begin{array}{l}\text { Dependent } \\
\text { variables }\end{array}$} \\
\hline & \multicolumn{2}{|c|}{$\begin{array}{l}\text { Employees } \\
\text { satisfaction }\end{array}$} & \multicolumn{2}{|c|}{ Market share } \\
\hline Innovation & $\begin{array}{l}196 * \\
*\end{array}$ & $\begin{array}{l}F: 16.34 \\
9 \\
P=000 \\
R^{2}: \\
0.4957\end{array}$ & $.124 *$ & $\begin{array}{l}\mathrm{F}: \\
51,205 \\
\mathrm{P}=000 \\
\mathrm{R}^{2}: \\
0.023 \\
\end{array}$ \\
\hline Risk taking & $198 * *$ & $\begin{array}{l}F: 6.944 \\
P=000 \\
R^{2}: \\
0.4231\end{array}$ & $\begin{array}{l}.374 * \\
*\end{array}$ & $\begin{array}{l}\mathrm{F}: 51.20 \\
5 \\
\mathrm{P}=000 \\
\mathrm{R}^{2}: \\
0.3974 \\
\end{array}$ \\
\hline $\begin{array}{l}\text { Proactivenes } \\
\mathrm{s}\end{array}$ & $.723 * *$ & $\begin{array}{l}\mathrm{F}: 52.45 \\
\mathrm{P}=000 \\
\mathrm{R}^{2}: \\
0.388\end{array}$ & $\begin{array}{l}.374 * \\
*\end{array}$ & $\begin{array}{l}\mathrm{F}: 44.56 \\
2 \\
\mathrm{P}=000 \\
\mathrm{R}^{2}: \\
0.3974\end{array}$ \\
\hline $\begin{array}{l}\text { Strategic } \\
\text { renewal }\end{array}$ & $.666^{* *}$ & $\begin{array}{l}\mathrm{F}: \\
18.421 \\
\mathrm{P}=000 \\
\mathrm{R}^{2}: \\
0.3012\end{array}$ & $\begin{array}{l}.411 * \\
*\end{array}$ & $\begin{array}{l}\mathrm{F}: \\
33.541 \\
\mathrm{P}=000 \\
\mathrm{R}^{2}: \\
0.2541 \\
\end{array}$ \\
\hline $\begin{array}{l}\text { Corporate } \\
\text { venturing }\end{array}$ & $.567 * *$ & $\begin{array}{l}F: 25 \\
864 \\
P=000 \\
R^{2}: \\
0.419 \\
\end{array}$ & $387 *$ & $\begin{array}{l}\text { F: } \\
42.554 \\
P=000 \\
R^{2}: \\
0.6812 \\
\end{array}$ \\
\hline
\end{tabular}

All of the paths were freely estimated, and error variances were constrained to one, which is the program default. The proposed structural equation model achieved a good fit $\left(\chi^{2}=459.93, \mathrm{df}=296, \mathrm{p}<0.00\right.$; GFI $=0.93, \mathrm{IFI}=0.96, \mathrm{CFI}=0.98, \mathrm{RMSEA}=0.091)$.

The findings revealed that innovation, risk taking, proactiveness, strategic renewal and corporate venturing are all significantly related with manufacturing firms' employees' satisfaction and the enhancement of their market share.

From the P-values associated with the coefficients, there is empirical evidence for rejecting the statistical hypotheses of nullity of the coefficients associated with the relationships between corporate entrepreneurship elements and manufacturing firms' nonfinancial performance. Innovation $(\mathrm{P}<0.05)$, risk-taking $(\mathrm{P}<0.05)$, proactiveness $(\mathrm{P}<0.05)$, strategic renewal $(\mathrm{P}<0.05)$ and corporate venturing $(\mathrm{P}<0.05)$. Therefore, we can confirm the existence of these relationships and should reject the null hypothesis $\left(\mathrm{H}_{0}\right)$ and accept the alternative hypothesis $\left(\mathrm{H}_{\mathrm{A}}\right)$.

The path coefficients are reported in Figure 1. 


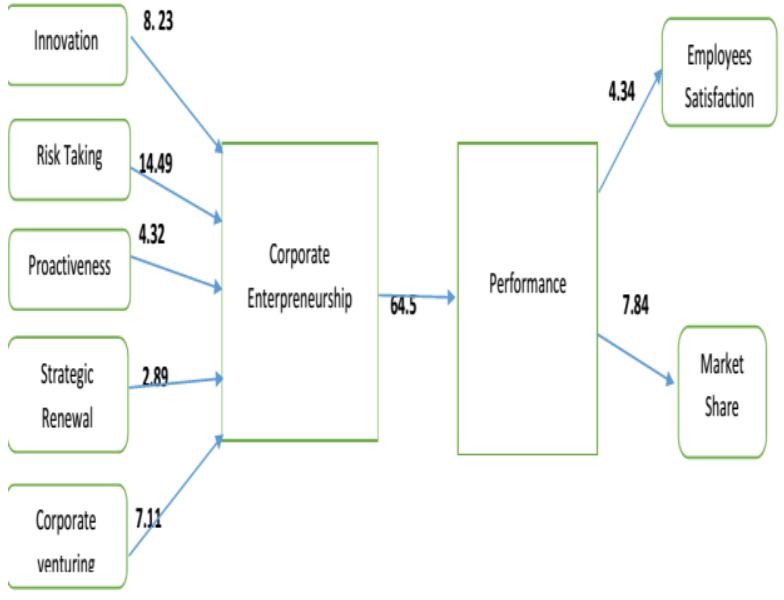

Figure 1. Path Coefficients

The estimated values of the coefficients of the structural equations provide relevant information about the ways in which corporate entrepreneurship elements affect manufacturing firms' performance. The result reveals that risk taking is the main element of corporate entrepreneurship driving manufacturing firms' performance. The path analysis also shows that the corporate entrepreneurship elements play a more significant role in determining the market share of manufacturing firms than its employees' satisfaction.

\section{Conclusion and Recommendations}

The study evaluates the effect of corporate entrepreneurship (measured by innovation, proactiveness, risk-taking, strategic renewal and corporate venturing) on the non-financial performance of manufacturing firms in Nigeria (measured by market share and employees satisfaction), using survey research design. The findings revealed that innovation, risk taking, proactiveness, strategic renewal and corporate venturing are all significantly related with manufacturing firms' nonfinancial performance (employees' satisfaction and market share).

The path-analysis revealed that risk taking has the highest effect on the non-financial performance of manufacturing firms in Nigeria, while innovation, corporate venturing, proactiveness and strategic renewal have the second, third, fourth and fifth highest effects respectively. Furthermore, the path analysis also revealed that corporate entrepreneurship elements play a more significant role in determining the market share of manufacturing firms than its employees' satisfaction.

It can therefore be concluded that $\mathrm{CE}$ elements (risk-taking, innovation, corporate venturing, proactiveness and strategic renewal) enhance manufacturing firms' non-financial performance (market share and employees' satisfaction). This is consistent with the study by Adele (2015), who studied the effect of $\mathrm{CE}$ on manufacturing firms' performance in Nigeria and found that CE significantly affects manufacturing firms' performance. But Adele (2015) focused majorly on financial performance measures. It is also consistent with the study by Abosede, Fayose and Eze (2018) that studied the effect of $\mathrm{CE}$ on the international performance of banks in Nigeria and found that CE significantly affects banks international performance.

It is recommended that manufacturing firms should employ CE elements towards the enhancement of their non-financial performance. Manufacturing firms should display a risk-tolerant posture towards performance enhancement. The managerial act of focusing on only ventures with expected return that are certain negatively affects firms' performance, in contrast to taking bold steps by entering the uncertain business environment (Eze, 2018; Lumpkin and Dess, 1996). Manufacturing firms should also strive to enhance their innovativeness, through the development of creative process and product as well as the creation of new market or the expansion of existing market. Strategic change, through the overall reengineering of the firm and taking advantage of business opportunities by venturing corporately are effective at this point.

\section{Suggestions for Further Studies}

This study only employed non-financial performance measures. However, further studies can be conducted using a combination of financial and nonfinancial performance measures like profitability, revenue, customers' satisfaction, efficiency, effectiveness and productivity. Further studies can also be conducted using interview, as this tends to yield more information from the respondents.

\section{References}

Abosede, A.J., Fayose, J., and Eze, B.U. (2018). Corporate entrepreneurship and international performance of banks in Nigeria. Journal of Economics and Management, 32(2), 5-17.

Abosede, A.J., Oladimeji, M.S., and Eze, B.U. (2017, November). Innovation and internationalization of banks in Nigeria. Paper presented at the Lagos State University International Conference of Business Administration, Lagos, Nigeria.

Adele, H. A. (2015). Corporate entrepreneurship as prerequisite for corporate financial performance of public liability companies: A study of selected manufacturing firms in Nigeria. International journal of economic development research and investment, 6(3), 118.

Akinmulegun, S.O. and Oluwole, F.O. (2014). An assessment of the Nigerian manufacturing sector in the era of globalization. American Journal of Social and Management Sciences, $5(1), 27-32$.

Burgelman, R. A. (1984). Designs for corporate entrepreneurship in established firms. California management review, 26(3), 154166. 
Central Bank of Nigeria (2012). Statistical bulletin. Retrieved from www.cbn.gov.ng.

Daryani, M.A., and Karimi, A. (2017). Effect of corporate entrepreneurship on firm performance in Iranian ASMEs: The mediating role of knowledge creation and learning orientation. Journal of agricultural science and technology, 19(2), 261-277.

Eze, B.U. (in press). Risk-taking, proactiveness and internationalization of Nigerian deposit money banks. Izvestiya Journal of Varna University of Economic.

Gunday, G., Ulusoy, G., Kilic, K., and Alpkan, L. (2011). Effects of innovation types on firms' performance. Middle East Journal of Scientific Research, 10(101), 662-667.

Hanan,M. (1976). Venturing corporations-Think small to stay strong. Harvard Business Review, 54(3), 139-148.

Hill, R. M., and Hlavacek, J. D. (1972). The venture team: a new concept in marketing organizations. Journal of Marketing, 36(1), $44-50$.

Jancenelle, V.E., Storrud-Barnes, S., and Javalgi, R.G. (2017). Corporate entrepreneurship and market performance: A content analysis of earnings conference calls. Management Research Review, 40 (3), 352-367.

Jennings, D. F., and Young, D. M. (1990). An empirical comparison between objective and subjective measures of the product innovation domain of corporate entrepreneurship. Entrepreneurship Theory and Practice, 15(1), 53-66.

Kuratko, D. F., and Montagno, R. V. (1989). The intrapreneurial spirit. Training and Development Journal, 43(10), 83-87.

Kuratko, D. F., Montagno, R. V., \& Hornsby, J. S. (1990). Developing an entrepreneurial assessment instrument for an effective corporate entrepreneurial environment. Strategic Management Journal, 11, 49-58.

Laleye, M. (2003). Public enterprises. In L. Adamolekun (Ed.), Public Administration in Africa, (pp. 2848), Abuja, Spectrum Books.

Miller, D., and Friesen, P. (1982). Innovation in Conservative and Entrepreneurial Firms: Two Models of Strategic Momentum. Strategic Management Journal.

Oburota, C.S., and Ifere, E.O. (2017). Manufacturing subsector and economic growth in Nigeria. British Journal of Economics, Management and Trade, 17(3), 1-9.
Oke, A. (2015). The impact of innovation performance. International Journal of Innovation in SMEs, 5(1), 13-25.

Oladimeji, M.S., Abosede, A.J., and Eze, B.U. (2017, November). Corporate entrepreneurship and service firms' performance in Nigeria. Paper presented at the Lagos State University International Conference of Business Administration, Lagos, Nigeria.

Oladimeji, M.S., Eze, B.U., and Adebayo, A.A. (in press). Strategic renewal, corporate venturing and internationalization of banks in Nigeria. Lapai Journal of Management Sciences.

Oyedokun, A.J. (2015). Corporate entrepreneurship and dynamic capabilities in selected pharmaceutical firms in Nigeria, International journal of management, 6(9), 121-135.

Peterson, R., and Berger, D. (1972). Entrepreneurship in organizations. Administrative Science Quarterly, 16, 97-106.

Pinchott, G. (1985). Intrapreneurship. New York: Harper \& Row.

Prange, C., and Pinho, J.C. (2017). How personal and organizational drivers impact on SME internationalizational performance: The mediating role of organization innovation. International business review.

Rauch, A., Wiklund, J., Lumpkin, G., and Frese, M. (2009). Entrepreneurial orientation and business performance: An assessment of past research and suggestions for the future. Entrepreneurship Theory and Practice, 33(3), 761-787.

Sathe, V. (1989). Fostering entrepreneurship in large diversified firm. Organizational Dynamics, 18(1), 20-32.

Schollhammer, H. (1982). Internal corporate entrepreneurship. In C. Kent, D. Sexton, \& K. Vesper (Eds.), Encyclopedia of entrepreneurship. Englewood Cliffs: PrenticeHall.

Thornberry, N.E. (2003). Corporate entrepreneurship: teaching managers to be entrepreneurs. Journal of management development, 22(4), 329-344.

Wiklund, J. (1999). The sustainability of entrepreneurial orientation-performance relationship. Entrepreneurship Theory and Practice, 24(1), 37-48.

Wolcot, R.C., \& Lippitz, M.J. (2007). The four models of corporate entrepreneurship. MIT Sloan management review, 49(1), 221-229. 
World Economic Forum (2013). Manufacturing sector adds value to economic growth and creates job. India: Press Trust.

Yamane, T. (1967). Statistics: An introductory analysis, 2nd edition, New York: Harper and Row.

Zahra, S. A. (1991). Predictors and financial outcomes of corporate entrepreneurship: an exploratory study. Journal of Business Venturing, 6(3), 259-286.

Zahra, S.A. (1995). Corporate entrepreneurship and financial performance: the case of management leveraged buyouts. Journal of Business Venturing, 10(3), 225-247.

Zahra, S. A. and Garvis, D. M. (2000). International Corporate Entrepreneurship and Firm Performance: The Moderating Effect of International Environment Hostility, Journal of Business Venturing, 15(2), 469-492. 